\author{
Харитонов М. М., доктор сільськогосподарських наук, \\ Лазарєва О. М., кандидат сільськогосподарських наук, \\ Лемішко С. М. старший викладач
}

Дніпропетровський державний аграрно-економічний університет

\title{
ЕКОЛОГІЧНА ОЦІНКА ВАРІАБЕЛЬНОСТІ ВМІСТУ НІТРАТІВ У ОВОЧЕВИХ ТА ПЛОДОВО-ЯГІДНИХ КУЛЬТУРАХ У ДНІПРОПЕТРОВСЬКІЙ ОБЛАСТІ
}

\author{
Рецензент - доктор сільськогосподарських наук В. Т. Сметанін
}

\begin{abstract}
Метою роботи є кількісне визначення вмісту нітратів в овочевій $і$ плодово-ягідній продукиії після проведення польових дослідів у Дніпропетровській області. Наведено результати визначення нітратів в овочах, плодах $і$ ягодах, щзо найчастіше використовують у раціоні харчування людини. Контроль вмісту нітратів здійснювався потенціометричним методом з використанням іоноселективного електроду. У результаті проведених досліджень встановлено найбільше перевищення ГДК в таких овочах: редис, буряк, морква і кабачки - із 6 проб 5 перевишують ГДК. Під час визначення вмісту нітратів у картоплі 12 проб із 46 перевищували ГДК, у капусті - 2 проби з 12, а у периі - 2 проби з 9 перевищували ГДК. За вмістом нітратів вивчені в нашій роботі фрукти та ягоди відносяться до групи за малою кониентрацією - до 100 мг/кг. Найменший вміст нітратів знайдено у зеленому горошку.
\end{abstract}

Ключові слова: овочі, фрукти, ягоди, нітрати, норма, гранично допустима концентрація.

Постановка проблеми. Переважним чином нітрати до організму людини надходять 3 овочами, фруктами та ягодами. У разі збалансованого харчового раціону на їх частку припадає близько $70 \%$ добової дози, решта потрапляе 3 водою, м'ясними та іншими продуктами [1].

У випадку тривалого вживання забруднених нітратами овочів, фруктів та води розвивається хронічна інтоксикація.

Під час вживання продуктів 3 підвищеним вмістом нітратів в організм людини надходять не тільки нітрати, але й їх метаболіти: нітрити і нітрозосполуки. Скласти точний баланс приходу i витрати нітратів в організмі поки не вдалося. Нітрати не тільки надходять в організм ззовні, але й утворюються в ньому.

Для дорослої людини гранично допустима норма нітратів - 5 мг на 1 кг маси тіла людини, тобто 0,25 г на людину вагою в 60 кг [2]. Для дитини допустима норма становить не більше 50 мг. Порівняно легко людина переносить денну дозу нітратів у 15-200 мг. 500 мг - це гранично допустима доза, а 600 мг - вже токсична доза для до- рослої людини.

Аналіз останніх досліджень і публікацій, у яких започатковано розв'язання проблеми. Азот - необхідний елемент для всіх форм життя. У процесі колообігу азоту в природі під час розщеплення білків та інших азотовмісних речовин виділяється аміак.

Нітрифікуючі бактерії окиснюють його до нітратів, а ті, в свою чергу, перетворюються на нітрити. Під дією денітрофікуючих бактерій останні знову перетворюються на азот, який знову потрапляє до атмосфери.

У грунти азот надходить з різними видами добрив, залишками рослин, амонійними та азотнокислими солями, які містяться в дощовій воді [3]. Нітрати - це природні продукти обміну всіх рослин. Вони життєво необхідні рослинам - без них неможливий їхній нормальний ріст і розвиток. Однак неконтрольоване використання азотних добрив призвело до накопичення необмеженого їх рівня у продуктах рослинного походження [5].

Аналіз вітчизняної та закордонної літератури показує, що на теперішній час рівень забруднення рослинної сировини нітратами достатньо високий.

До основних факторів, які викликають накопичення нітратів в овочевій, плодово-ягідній продукції відносяться метеорологічні та агротехнічні умови вирощування культур, рівень родючості грунтів, сортові ознаки рослин [3].

Науковцями досліджені фрукти та овочі, районовані у східній Україні, на предмет умісту в них токсичних речовин, залежно від їх видової та сортової належності (морква, буряк, гарбуз, перець, кабачки, томати, ревень, агрус та ін.), а також в їх анатомічних складових.

Ці дослідження дали змогу виявити найбільш безпечні сільськогосподарські культури та їх сорти.

Вивчення закономірностей надходження і накопичення в рослинах нітратів необхідне для правильного обгрунтування розробки заходів, що знижують їхній вміст у готовій продукції. 


\section{СІЛЬСЬКЕ ГОСПОДАРСТВО. РОСЛИННИЦТВО}

Мета досліджень була пов'язана із визначенням варіабельності вмісту нітратів в овочевій і плодово-ягідній продукції у польових дослідах 3 різними сортами.

Головними завданнями було:

a) сформувати базу даних визначення вмісту нітратів в овочевій та плодово-ягідній продукції;

б) визначити рослини-акумулятори нітратів та визначити кількість проб, які перевищують ГДК.

Матеріали і методи досліджень. Дослідження були проведені у польових дослідах з видами і сортами овочевих та плодово-ягідних культур, районованих у степовій зоні України.

Польові досліди були закладені у 4-кратній повторності в умовах овочево-баштанної станції двох державних сортодільниць у селі Олександрівка, Дніпропетровського району та н. п. Дослідний, м. Дніпропетровськ, Дніпропетровської області у 2000-2004 та 2014 роки.

Середні проби овочів, плодів і ягід подрібнювали та гомогенізували. Потім зважували з 10 г подрібненого зразка або вичавленого соку, додавали 50 мл $1 \%$ розчину алюмокалієвих галунів $\mathrm{i}$ екстрагували нітрати протягом 15 хвилин.

Контроль нітратів здійснювали стандартним потенціометричним методом із застосуванням іоноселективного електроду [4].
Оцінку випадків перевищення встановлених гранично допустимих концентрацій (ГДК) робили з урахуванням декількох джерел $[2,5-6]$.

Результати досліджень. Отримані результати визначення вмісту нітратів в овочевих культурах наведені в таблиці 1. 3 даних таблиці 1 видно, що зі 111 зразків, які досліджувалися на вміст нітратів, 36 перевищують гранично допустиму концентрацію.

Найбільша частка перевищення ГДК спостерігається в таких овочах: редис, буряк, морква i кабачки - із 6 проб 5 перевищують ГДК.

Під час визначення вмісту нітратів у картоплі 12 проб з 46 перевищували ГДК, у капусті - 2 проби 3 12, а у перці - 2 проби 39 перевищували ГДК. Перевищення ГДК не спостерігалось у помідорах.

Результати визначення концентрації нітратів у фруктах та ягодах наведені в таблиці 2.

Середнє значення нітратів у плодах та ягодах знаходилось у межах 20-50 мг/кг.

Згідно 3 проведеними раніше дослідженнями [7] за вмістом нітратів вивчені в нашій роботі фрукти та ягоди відносяться до групи 3 малою концентрацією - до 100 мг/кг.

\section{1. Концентрація нітратів в овочевих культурах, мг/кг}

\begin{tabular}{|c|c|c|c|c|c|}
\hline Овочева культура & $\begin{array}{c}\text { Кількість } \\
\text { зразків }\end{array}$ & $\begin{array}{c}\text { Середнє } \\
\text { значення }\end{array}$ & Min-Max & ГДК & $\begin{array}{c}\text { Кількість проб, які } \\
\text { перевищують ГДК }\end{array}$ \\
\hline Редис & 5 & 2727,6 & $2022-3596$ & 1500 & 5 \\
\hline Буряк & 6 & 2886,5 & $1276-4527$ & 1400 & 5 \\
\hline Морква & 6 & 485,0 & $161-1137$ & 250 & 5 \\
\hline Кабачки & 6 & 669 & $291-1157$ & 400 & 5 \\
\hline Картопля & 46 & 138,2 & $23-639$ & 250 & 12 \\
\hline Капуста & 12 & 584,33 & $103-1833$ & 900 & 2 \\
\hline Перець & 9 & 228,75 & $73-580$ & 200 & 0 \\
\hline Помідори & 19 & 44,1 & $16,5-82,0$ & 150 & \\
\hline Зелений горошок & 9 & 4,6 & $3,6-6,4$ & & \\
\hline
\end{tabular}

2. Вміст нітратів у фруктах та ягодах

\begin{tabular}{|c|c|c|c|}
\hline Фрукти, ягоди & Кількість зразків & $\begin{array}{c}\text { Середнє } \\
\text { значення }\end{array}$ & Max-Min \\
\hline Слива & 7 & 50,4 & $23,9-81,9$ \\
\hline Черешня & 24 & 15,8 & $8,05-27,6$ \\
\hline Абрикос & 6 & 45,6 & $20,3-82,0$ \\
\hline Алича & 4 & 40,7 & $28,9-51,7$ \\
\hline Полуниця & 5 & 42,0 & $34,9-50,5$ \\
\hline Малина & 7 & 33,3 & $16,2-91,4$ \\
\hline Смородина & 17 & 22,8 & $14,4-28,7$ \\
\hline
\end{tabular}


Висновок. У результаті проведених досліджень встановлено найбільше перевищення ГДК в таких овочах: редис, буряк, морква і кабачки - із 6 проб 5 перевищують ГДК.

Під час визначення вмісту нітратів у картоплі 12 проб з 46 перевищували ГДК, у капусті - 2 проби з 12, а у перці - 2 проби 39 перевищували

\section{БІБЛІОГРАФІЯ}

1. Дорогунцов C. I. Екологія / С. І. Дорогунцов, К. Ф. Коценко, М. А. Хвесик. - К. : КНЕУ, 2005. $371 \mathrm{c}$.

2. Габович Р. Д. Гигиенические основы охраны продуктов питания от вредных химических веществ / Р. Д. Габович, Л. С. Припутина. - К. : Здоровье, 1987. - 248 с.

3. Дегодюк Е. Г. Вирощування екологічно чистої продукції рослинництва / Е. Г. Дегодюк. - К. : Урожай, 2007. - 317 с.

4. Продукти переробки плодів і овочів. Методи визначення нітратів в овочах. Методика визначення нітратів і нітритів у продуктах рослинництва : ДСТУ 29270 - 95, № 5048 - 89. -
гДК.

За вмістом нітратів вивчені в нашій роботі фрукти та ягоди відносяться до групи з малою концентрацією - до 100 мг/кг.

Найменший вміст нітратів знайдено у зеленому горошку.

(Національний стандарт України).

5. Циганенко O. I. Нітрати в харчових продуктах / О. І. Циганенко. - К. : Здоров'я, 2005. C. $141-145$

6. Ополь Н. И. Нитраты / Н. И. Ополь, Е. В. Добрянская. - Кишинев : Штиинца, 1986. $116 \mathrm{c}$.

7. Моніторинг нітратів та заходи щодо їх зменшення у рослинній продукції / [В. Д. Ганчук, М. Г. Христіансен, О. М. Бутенко, Г. М. Біла, В. Г. Дроков] // Восточно-Европейский журнал передовых технологий ISSN 1729-3774. - 2012. №6/6 (60). - C. 47-48. 